\title{
Long-term orange juice consumption is associated with low LDL-cholesterol and apolipoprotein B in normal and moderately hypercholesterolemic subjects
}

\author{
Nancy P Aptekmann and Thais B Cesar
}

\begin{abstract}
Background: This study investigated the hypothesis that long-term orange juice consumption ( $\geq 12$ months) was associated with low risk factors for cardiovascular disease in adult men and women with normal and moderately high cholesterol blood levels.

Methods: The sample consisted of 103 men (18-66 y) and 26 women (18-65y); all were employees of an orange juice factory with daily access to free orange juice. The results showed that $41 \%$ of the individuals consumed 2 cups $(480 \mathrm{~mL}$ ) of orange juice per day for at least twelve months, while $59 \%$ of the volunteers are non-consumers of orange juice.

Results: Orange juice consumers with normal serum lipid levels had significantly lower total cholesterol $(-11 \%, \mathrm{p}<0.001)$, LDL-cholesterol $(-18 \%, \mathrm{p}<0.001)$, apolipoprotein B (apo B) $(-12 \%, \mathrm{p}<0.01)$ and LDL/HDL ratio $(-12 \%, p<0.04)$ in comparison to non-consumers, as did the consumers with moderate hypercholesterolemia: lower total cholesterol $(-5 \%, p<0.02)$, LDL-cholesterol $(-12 \%, p<0.03)$, apolipoprotein $\mathrm{B}(-12 \%, \mathrm{p}<0.01)$ and $\mathrm{LDL} / \mathrm{HDL}$ ratio $(-16 \%, \mathrm{p}<0.05)$ in comparison the non-consumers counterparts. Serum levels of homocysteine, HDL- cholesterol and apolipoprotein A-1, body composition and the dietary intake of food energy and macronutrients did not differ among orange juice consumers and non-consumers, but vitamin $C$ and folate intake was higher in orange juice consumers.
\end{abstract}

Conclusion: Long-term orange juice consumers had lower levels of total cholesterol, LDL-cholesterol, apo $B$ and $L D L / H D L$ ratio and an improvement of folate and vitamin $C$ in their diet.

Keywords: Orange juice, LDL-cholesterol, Apo B, Homocysteine, Humans

\footnotetext{
* Correspondence: tcesar@fcfar.unesp.br

Department of Food and Nutrition, School of Pharmaceutical Sciences,

UNESP - Univ Estadual Paulista, Araraquara, SP 14801-902, Brazil
} 


\section{Resumo}

Introdução: $O$ presente estudo investigou a hipótese de que o consumo de suco de laranja a longo prazo ( $\geq 12$ meses) foi associado com menor fator de risco para doença cardiovascular em homens e mulheres adultos com nível normal e moderadamente alto de colesterol no sangue.

Métodos: A amostra foi composta por 103 homens (18-66 anos) e 26 mulheres (18-65 anos) todos eram funcionários de uma fábrica de suco de laranja com acesso diário e gratuito ao suco de laranja. Os resultados mostraram que $41 \%$ dos indivíduos consumiram dois copos (480 mL) de suco de laranja por dia durante pelo menos 12 meses, enquanto 59\% dos voluntários não eram consumidores de suco de laranja.

Resultados: Os consumidores de suco de laranja com níveis normais de lipídeos séricos apresentaram menor teor de colesterol total $(-11 \% \mathrm{p}<0.001)$, LDL-colesterol (-18\%, p <0.001), apolipoproteína B (apo B) $(-12 \%, p<0.01)$ e LDL/HDL $(-12 \%, p<0.04)$ em comparação com os não-consumidores; assim como os consumidores com hipercolesterolemia moderada (-5\% p <0.02), LDL-colesterol (-12\%, p <0.03), apolipoproteína B $(-12 \%, p<0.01)$ e LDL/HDL (-16\%, p <0.05) em comparação aos seus pares de não-consumidores. Os níveis séricos de homocisteína, HDL-colesterol e apolipoproteína A-1, a composição corporal e a ingestão de energia e de macronutrientes da dieta não diferiram entre os consumidores de suco de laranja e não-consumidores, mas a vitamina $C$ e o folato estavam mais elevados na dieta nos consumidores de suco de laranja.

Conclusão: Os consumidores de suco de laranja de longo prazo apresentaram menores níveis de colesterol total, LDL-colesterol, apo B e razão LDL/HDL e uma melhoria nos níveis de folato e vitamina C nas suas dietas.

Palavras-chave: Suco de laranja LDL-colesterol, Apo B, Homocisteína, Humanos

\section{Background}

Consumption of fruits and vegetables is associated with a lower risk of coronary artery disease and this effect is attributed mainly to the functional and antioxidant actions of vitamins and phytochemicals, such as phenolic compounds and flavonoids [1-5]. In developed countries, foods such as wine, grapes and tea provide the greatest proportion of dietary flavonoids, followed by citrus fruits and orange juice [6]. Non-starchy vegetables and fruits, such as lettuce, tomatoes, onions and citrus provide 60 to $106 \mathrm{mg}$ of flavonoids per day to the Brazilian diet, and oranges and fresh squeezed orange juice are responsible for more than $70 \%$ of the total flavonoid intake [7].

Orange juice contains considerable amounts of flavonoids, mainly hesperidin, and its content is related to juice processing conditions. Experimental studies have shown that hesperidin has anti-inflammatory, antiallergic, hypolipidemic and anticarcinogenic properties [7-12]. These flavonoids help to lower serum levels of LDL-cholesterol [13-15] and apo B [16,17], and can reduce triglycerides [16] and increase HDL-cholesterol [18], reducing risk of coronary artery disease $[10,19,20]$. The antioxidant effect of vitamin $C$ is vasoprotective $[20,21]$ and even small amounts of folate have been associated with lower homocysteine levels and less thromboembolic events [22].

Dyslipidemias are the main risk factors for the development of atherosclerosis, followed by visceral fat and obesity, which are related to higher rates of morbidity and mortality from coronary artery disease [23]. Lower total and LDL-cholesterol levels have been associated with decreased risk of coronary artery disease and related conditions, and thus vegetable-based diets are recommended for the treatment of dyslipidemias, not only because of low saturated fat and cholesterol, but also because of the significant amounts of micronutrients and bioactive compounds [24-26].

The actions of citrus flavonoids have been investigated in clinical and experimental studies, but most studies used high doses of isolated forms of these compounds, such as hesperidin or naringin $[5,16,27]$. Clinical studies with normolipidemic and hypercholesterolemic subjects committed to a regular consumption of orange juice have shown decreased LDL-cholesterol levels [13,14] and increased HDL-cholesterol levels [18]. However, these effects were not yet investigated in subjects with noncontrolled long-term daily orange juice consumption.

The present cross-sectional study investigated the hypothesis that a daily long-term consumption of orange juice is associated with an improvement of lipid profile and as such, helps to lower the risk factors of cardiovascular disease in normolipidemic and moderately hypercholesterolemic adults. To test this hypothesis we compared biochemical, anthropometric and dietary parameters of regular consumers and non-consumers of commercially processed orange juice. To avoid external influences, none of the subjects were under cholesterol-lowering medication.

\section{Results}

All women $(n=36)$ and $62 \%$ of the men $(n=64)$ had normal serum cholesterol levels (total cholesterol $<6.2 \mathrm{mmol} / \mathrm{L}$ ) and $38 \%$ of the men $(n=39)$ had moderately high serum cholesterol levels (total cholesterol $\geq 6.2 \mathrm{mmol} / \mathrm{L}$ ). The 
individuals were divided by total serum cholesterol and gender to study the anthropometric and dietary variables and only by total serum cholesterol to study the biochemical variables.

Nutritional assessment of the men and women with normal and men with high total cholesterol levels, grouped according to orange juice consumption, revealed no differences among the groups regarding daily intake of food energy, protein, carbohydrate, dietary fiber, total fruit, total fat, saturated fat, cholesterol and potassium ( $p>0.05$ ) (Table 1). However, vitamin $\mathrm{C}$ and folate intakes, calculated from the 24-hour recall, were greater in individuals who consumed orange juice regularly than in those who did not, regardless of group $(\mathrm{p} \leq 0.05)$ (Table 1). The mean orange juice intake of regular consumers, regardless of gender, was $480 \pm 158 \mathrm{~mL} / \mathrm{d}$, ranging from 240 to $720 \mathrm{~mL} / \mathrm{d}$. In women, the mean orange juice intake was $390 \pm 149 \mathrm{~mL} / \mathrm{d}$, representing $7.9 \%$ of the total dietary energy and $14.6 \%$ of the total dietary carbohydrate. In men, regardless of cholesterol level, the mean orange juice intake was $476 \pm 158 \mathrm{~mL} / \mathrm{d}$, representing $7.8 \%$ of the total dietary energy and $15.3 \%$ of the total dietary carbohydrate. Therefore, the percentage energy and carbohydrate intakes from orange juice for men and women were very similar (Table 1).

Among women, $68 \%$ had a normal BMI and 32\% exceeded the normal range. On the other hand, $42 \%$ of the men were normal weight and 58\% were overweight and obese ( 80 and $20 \%$ respectively). These results suggested that a large percentage of the participants in this investigation were overweight; that is, $32 \%$ of the women and $58 \%$ of the men. Comparison of the anthropometric variables of all groups with normal and high cholesterol levels showed that regular orange juice consumption was not associated with body weight, BMI, waist circumference or percentage of body fat $(\mathrm{p}>0.05)$ (Table 2). Hypercholesterolemia was present in $38 \%$ of the men, especially in those with excessive weight and increased waist circumference, while normocholesterolemic women and men showed an average BMI within normal range.

The comparison of physical activity levels between orange juice consumers and non-consumers (Table 2) showed no statistical differences $(p>0.05)$. In fact, the average physical activity coefficient (PA) ranged from 1.11 to 1.18 , meaning low physical activity for both genders, among consumers and non-consumers, according to DRI-2005 [28]. The percentage of volunteers with sedentary or low active life style was higher $(\geq 55 \%)$ than the active subjects in all groups $(\leq 45 \%)$. Very active subjects were only detected among normolipidemic men, in very low proportion (3\%).

Biochemical data of men and women with normal cholesterol levels and men with high cholesterol levels are presented in Table 3. Normolipidemic individuals

Table 1 Nutrient intake of orange juice consumers and non-consumers according to gender and serum cholesterol level

\begin{tabular}{|c|c|c|c|c|c|c|}
\hline \multirow{3}{*}{$\frac{\text { Subjects }}{n}$} & \multicolumn{4}{|c|}{ Normolipidemic $^{\#}$} & \multirow{2}{*}{\multicolumn{2}{|c|}{$\begin{array}{c}\text { Hypercholesterolemic }^{\# \#} \\
\text { Men }\end{array}$}} \\
\hline & \multicolumn{2}{|c|}{ Women } & \multicolumn{2}{|c|}{ Men } & & \\
\hline & 18 & 8 & 38 & 26 & 23 & 16 \\
\hline Orange juice & Non-consumers & Consumers & Non-consumers & Consumers & Non-consumers & Consumers \\
\hline $\mathrm{mL} / \mathrm{d}$ & 0 & $390 \pm 149$ & 0 & $466 \pm 163$ & 0 & $486 \pm 145$ \\
\hline $\mathrm{MJ} / \mathrm{d}$ & 0 & $0.74 \pm 0.28$ & 0 & $0.89 \pm 0.30$ & 0 & $0.92 \pm 0.27$ \\
\hline Total Energy(MJ/d) & $8.01 \pm 2.02$ & $9.44 \pm 2.25$ & $11.5 \pm 5.04$ & $11.6 \pm 2.51$ & $12.0 \pm 2.88$ & $11.8 \pm 2.0$ \\
\hline Protein $(\mathrm{g} / \mathrm{d})$ & $83.1 \pm 28.4$ & $112 \pm 38.7$ & $117 \pm 20.1$ & $125 \pm 28.4$ & $132 \pm 33.6$ & $143 \pm 25.8$ \\
\hline Carbohydrate $(\mathrm{g} / \mathrm{d})$ & $233 \pm 97.3$ & $307 \pm 104$ & $327 \pm 111$ & $346 \pm 113$ & $382 \pm 123$ & $367 \pm 72.3$ \\
\hline Dietary fiber $(\mathrm{g} / \mathrm{d})$ & $12.0 \pm 6.8$ & $14.7 \pm 10.0$ & $23.5 \pm 12.2$ & $25.2 \pm 14.0$ & $27.0 \pm 14.0$ & $23.4 \pm 11.6$ \\
\hline Total fruits $(\mathrm{g} / \mathrm{d})$ & $93 \pm 95$ & $89 \pm 114$ & $138 \pm 184$ & $94 \pm 149$ & $157 \pm 197$ & $125 \pm 138$ \\
\hline Total fat $(\mathrm{g} / \mathrm{d})$ & $61.5 \pm 22.1$ & $62.2 \pm 10.6$ & $94.5 \pm 32.4$ & $98.6 \pm 28.2$ & $90.3 \pm 37.8$ & $90.6 \pm 27.4$ \\
\hline Saturated fats $(\mathrm{g} / \mathrm{d})$ & $19.3 \pm 9.37$ & $18.9 \pm 4.79$ & $30.1 \pm 12.35$ & $31.3 \pm 10.3$ & $27.8 \pm 10.2$ & $29.3 \pm 12.8$ \\
\hline Cholesterol (mg/d) & $211 \pm 137$ & $317 \pm 62.4$ & $316 \pm 113$ & $345 \pm 109$ & $317 \pm 116$ & $345 \pm 123$ \\
\hline Vitamin C (mg/d) & $107 \pm 108$ & $221 \pm 252^{*}$ & $138 \pm 115$ & $227 \pm 121^{*}$ & $174 \pm 120$ & $273 \pm 158^{*}$ \\
\hline Folate $(\mu \mathrm{g} / \mathrm{d})$ & $211 \pm 108$ & $307 \pm 140^{*}$ & $393 \pm 138$ & $500 \pm 148^{*}$ & $423 \pm 146$ & $538 \pm 166^{*}$ \\
\hline Potassium (g/d) & $3.5 \pm 1.2$ & $3.8 \pm 1.7$ & $3.6 \pm 1.0$ & $4.2 \pm 1.1^{*}$ & $4.2 \pm 1.2$ & $4.2 \pm 0.9$ \\
\hline
\end{tabular}

Data are expressed as means \pm SD.

Statistical comparison (test $\mathrm{t}$ ) was between non-consumers and consumers groups of normolipidemic women, normolipidemic men, and hypercholesterolemic men *p $<0.05$.

\# Normolipidemic: total cholesterol $<6.2 \mathrm{mmol} / \mathrm{L}$.

\#\#Hypercholesterolemic: total cholesterol $\geq 6.2 \mathrm{mmol} / \mathrm{L}$. 
Table 2 Anthropometric and physical activity parameters of orange juice consumers and non-consumers according to gender and serum cholesterol level

\begin{tabular}{|c|c|c|c|c|c|c|}
\hline \multirow{3}{*}{$\frac{\text { Subjects }}{\mathrm{n}}$} & \multicolumn{4}{|c|}{ Normolipidemic } & \multirow{2}{*}{\multicolumn{2}{|c|}{$\begin{array}{c}\text { Hypercholesterolemic } \\
\text { Men }\end{array}$}} \\
\hline & \multicolumn{2}{|c|}{ Women } & \multicolumn{2}{|c|}{ Men } & & \\
\hline & 18 & 8 & 38 & 26 & 23 & 16 \\
\hline Orange juice & Non-consumers & Consumers & Non-consumers & Consumers & Non-consumers & Consumers \\
\hline $\mathrm{mL} / \mathrm{d}$ & 0 & $390 \pm 149$ & 0 & $466 \pm 163$ & 0 & $486 \pm 145$ \\
\hline Age (years) & $37.6 \pm 10.2$ & $39.2 \pm 12.2$ & $36.8 \pm 9.92$ & $33.8 \pm 10.9$ & $41.9 \pm 9.8$ & $40.8 \pm 8.0$ \\
\hline Weight (kg) & $64.0 \pm 12.4$ & $63.2 \pm 10.6$ & $75.9 \pm 11.4$ & $70.8 \pm 10.0$ & $78.5 \pm 13.8$ & $83.0 \pm 10.5$ \\
\hline $\mathrm{BMI}\left(\mathrm{kg} / \mathrm{m}^{2}\right)$ & $24.5 \pm 4.36$ & $24.6 \pm 4.99$ & $25.1 \pm 3.63$ & $23.8 \pm 2.89$ & $26.6 \pm 2.8$ & $27.0 \pm 3.4$ \\
\hline Body fat (\%) & $36.7 \pm 4.45$ & $33.9 \pm 6.53$ & $27.8 \pm 5.03$ & $25.1 \pm 7.52$ & $28.0 \pm 5.7$ & $27.0 \pm 4.1$ \\
\hline Waist circ.(cm) & $82.5 \pm 10.5$ & $88.5 \pm 12.3$ & $90.4 \pm 9.96$ & $87.5 \pm 9.33$ & $96.3 \pm 8.2$ & $97.5 \pm 9.3$ \\
\hline \multicolumn{7}{|l|}{ Physical Activity } \\
\hline$P A^{\# \# \#}$ & $1.11 \pm 0.11$ & $1.16 \pm 0.13$ & $1.17 \pm 0.11$ & $1.15 \pm 0.10$ & $1.18 \pm 0.08$ & $1.17 \pm 0.11$ \\
\hline Duration (h/d) & $0.66 \pm 0.61$ & $0.50 \pm 0.44$ & $1.18 \pm 1.23$ & $1.06 \pm 0.79$ & $0.89 \pm 0.48$ & $0.80 \pm 0.64$ \\
\hline Frequency (times/wk) & $2.39 \pm 2.59$ & $3.38 \pm 2.83$ & $2.94 \pm 2.37$ & $2.75 \pm 2.27$ & $2.72 \pm 1.74$ & $3.23 \pm 2.17$ \\
\hline Sedentary ${ }^{\# \# \# ~(\%) ~}$ & 56 & 38 & 16 & 15 & 5 & 29 \\
\hline Low Active (\%) & 11 & 38 & 37 & 46 & 50 & 31 \\
\hline Active (\%) & 33 & 25 & 45 & 38 & 45 & 40 \\
\hline Very Active (\%) & 0 & 0 & 3 & 0 & 0 & 0 \\
\hline
\end{tabular}

Data are expressed as means \pm SD.

Statistical comparison (test $\mathrm{t}$ ) was between non-consumers and consumers groups of normolipidemic women and men, and hypercholesterolemic men

${ }^{*} \mathrm{p}<0.05$.

\# Normolipidemic: total cholesterol $<6.2 \mathrm{mmol} / \mathrm{L}$.

\#\#ypercholesterolemic: total cholesterol $\geq 6.2 \mathrm{mmol} / \mathrm{L}$.

\#\#\# PA is the physical activity coefficient according to DRI (2005).

\#\#\#\# \% individuals with Sedentary, Low Active, Active or Very Active life style.

Table 3 Biochemical characteristics of orange juice consumers and non-consumers according to gender and serum cholesterol level

\begin{tabular}{|c|c|c|c|c|}
\hline \multirow[b]{2}{*}{$n$} & \multicolumn{2}{|c|}{ Normolipidemic } & \multicolumn{2}{|c|}{ Hypercholesterolemic } \\
\hline & 56 & 34 & 23 & 16 \\
\hline Orange juice & Non-consumers & Consumers & Non-consumers & Consumers \\
\hline $\mathrm{mL} / \mathrm{d}$ & 0 & $530 \pm 188$ & 0 & $486 \pm 145$ \\
\hline Triacylglycerol (mmol/L) & $1.15 \pm 0.37$ & $1.11 \pm 0.55$ & $1.86 \pm 0.63$ & $2.16 \pm 1.12$ \\
\hline \multicolumn{5}{|l|}{ Cholesterol (mmol/L) } \\
\hline Total & $5.08 \pm 0.70$ & $4.54 \pm 0.78^{*}$ & $6.77 \pm 0.41$ & $6.40 \pm 0.58^{*}$ \\
\hline $\mathrm{HDL}$ & $1.20 \pm 0.29$ & $1.16 \pm 0.31$ & $1.14 \pm 0.27$ & $1.16 \pm 0.23$ \\
\hline LDL & $3.35 \pm 0.61$ & $2.74 \pm 0.80^{*}$ & $4.78 \pm 0.48$ & $4.20 \pm 0.86^{*}$ \\
\hline LDL/HDL ratio & $2.93 \pm 0.86$ & $2.57 \pm 2.57^{*}$ & $4.46 \pm 1.25$ & $3.73 \pm 1.00^{*}$ \\
\hline \multicolumn{5}{|l|}{ Apolipoprotein (g/L) } \\
\hline$A-1$ & $1.40 \pm 0.25$ & $1.36 \pm 0.25$ & $1.41 \pm 0.28$ & $1.39 \pm 0.18$ \\
\hline B & $0.90 \pm 0.19$ & $0.79 \pm 0.21^{*}$ & $1.27 \pm 0.17$ & $1.12 \pm 0.17^{*}$ \\
\hline Homocysteine $(\mu \mathrm{mol} / \mathrm{L})$ & $9.95 \pm 2.81$ & $9.17 \pm 2.31$ & $11.1 \pm 2.53$ & $10.0 \pm 2.31$ \\
\hline
\end{tabular}

Data are expressed as means \pm SD.

Statistical comparison (test t) was between consumers and non-consumers groups of normolipidemic and hypercholesterolemic individuals.

${ }^{*} \mathrm{p}<0.05$.

\# Normolipidemic: total cholesterol $<6.2 \mathrm{mmol} / \mathrm{L}$

\#\#Hypercholesterolemic: total cholesterol $\geq 6.2 \mathrm{mmol} / \mathrm{L}$. 
who consumed orange juice regularly had lower total cholesterol (-11\%), LDL-cholesterol (-18\%), LDL/HDL ratio $(-12 \%)$, and apo $\mathrm{B}(-12 \%)$ in comparison to normolipidemics without orange juice consumption $(\mathrm{p} \leq 0.05)$. Similarly, hyperlipidemic men who consumed orange juice showed lower total cholesterol $(-5 \%)$, LDL-cholesterol $(-12 \%)$, apo B $(-12 \%)$ and LDL/HDL ratio $(-16 \%)$ in comparison to those without orange juice consumption $(\mathrm{p} \leq 0.05)$ (Table 3$)$. Although we did not investigate the family history of heart disease in this study, the identification of the hypercholesterolemic subjects showed the genetic heritage for heart disease in this group of people. On the other hand, triglycerides, HDL-cholesterol, apo A-I and homocysteine did not show any difference between consumers and non-consumers of orange juice $(\mathrm{p}>0.05)$ (Table 3). All individuals had normal homocysteine levels (IMx Metabolic - Homocysteine, Abbott Laboratory).

Significant inverse correlations (data not showed) were found between regular orange juice intake and the following biochemical variables: total cholesterol $(\mathrm{r}=-0.35, \mathrm{p}<0.001)$, LDL-cholesterol $(\mathrm{r}=-0.38, \mathrm{p}<0.001)$, apo $B(r=-0.30, p<0.003)$ and LDL/HDL ratio $(r=-0.24$, $\mathrm{p}<0.02)$ in men and women with normal cholesterol levels. Significant inverse correlations were also found between regular orange juice intake and total cholesterol $(r=-0.31$, $\mathrm{p}<0.05)$, LDL-cholesterol $(\mathrm{r}=-0.39, \mathrm{p}<0.02)$ and apo $\mathrm{B}$ $(\mathrm{r}=-0.31, \mathrm{p}<0.05)$ in men with high cholesterol levels. An inverse correlation was found between men with regular orange juice intake and homocysteine levels $(r=-0.20, p<0.05)$, and homocysteine levels and apo A-I $(\mathrm{r}=-0.30, \mathrm{p}<0.001)$, while a positive correlation was found between homocysteine levels and triglycerides $(\mathrm{r}=0.17, \mathrm{p}<0.04)$.

\section{Discussion}

Recent studies have debated the nutritional risks and benefits of the regular consumption of fruit juices related to the increase of overweight and obesity [6,29-32]. There are some suggestions that calorie-free or low food energy content beverages (water, tea, coffee, low fat milk, skim milk, soy beverages) and non-calorically sweetened beverages, should be preferred to beverages with some nutritional benefits, such as fruit and vegetable juices, whole milk, alcoholic beverages and sports drinks, to prevent weight gain $[29,31]$. However, others have shown that consumption of pure fruit juices, without added sweeteners, did not contribute to weight gain $[6,30,32]$, but protected against chronic diseases such as coronary heart disease and some cancers [33] because of the contribution of bioactive compounds, including flavonoids and vitamins. The statement that the consumption of orange juice contributes to the development of weight gain and obesity was not confirmed in the present study nor by a recent epidemiological study with children [34], since orange juice consumption was not associated with body weight, body fat, waist circumference, obesity or physical activity in this study. The majority of the consumers and non-consumers of orange juice showed low physical activity with no statistical difference among groups. So, we suggested that physical activity had no influence on the singularities detected on the markers of lipid metabolism or on the intake of vitamin $\mathrm{C}$ and folate, which were influenced by the consumption of orange juice.

Together with excess weight, visceral fat can promote metabolic disorders, such as insulin resistance, dyslipidemias and high blood pressure [22,35]. In our work, the percentage abdominal obesity among orange juice consumers did not differ from that of non-consumers. A meta-analysis showed that high consumption of fruits, juices and non-starchy vegetables may change body composition, reflected in BMI and abdominal obesity. Hence, consumption of these fresh foods may not help to reduce weight and waist circumference, but may help to delay or prevent their increase [36,37]. Also, orange juice has high nutritional density with low food energy content [38] in comparison with other unfortified juices and beverages, and helps consumers to meet the nutritional requirements of vitamin $\mathrm{C}$, folate and potassium [39]. Orange juice can be considered a safe and protective energy source since it protects against oxidative or inflammatory stress [36].

Most participants of the present study followed a similar diet, since they had the two main meals of the day, breakfast and lunch, at the company's restaurant from Monday through Friday. According to the dietary recalls, there was no difference among orange juice consumers and non-consumers regarding dietary energy, protein, carbohydrate, dietary fibers, total fruit, total fat, cholesterol, and potassium consumption. Moreover, the orange juice consumers showed significantly higher intake of vitamin C and folate, attributable to their average orange juice intake $(480 \mathrm{~mL} / \mathrm{d})$. A previous experiment [18] verified a linear increase of vitamin $C$ in the blood serum with increasing doses of orange juice, from 250 to $750 \mathrm{~mL}$, while serum folate concentration only increased significantly when orange juice consumption reached $750 \mathrm{~mL} / \mathrm{d}$, suggesting that folate bioavailability is limited by its source and concentration in food.

Folate supplementation can decrease the homocysteine of individuals with originally normal and high levels, with dietary folate providing a beneficial impact on homocysteine levels [40]. Orange juice is one of the most common sources of folate in the human diet: $250 \mathrm{~mL}$ of orange juice contains $47 \mu \mathrm{g}$ of folate [41], which may help to control serum homocysteine levels [18]. A mean orange juice intake of $480 \mathrm{~mL} / \mathrm{d}$ provides an increase in dietary 
folate intake of $90 \mu \mathrm{g} / \mathrm{d}$, and as much as $141 \mu \mathrm{g} / \mathrm{d}$ for those who consume $720 \mathrm{~mL}$ of orange juice. Most likely these increased folate intakes were responsible for the significant inverse correlation that was detected in the present study between orange juice and serum homocysteine levels, observed only for males.

The serum homocysteine levels of men with normal and high cholesterol levels who consumed orange juice daily did not differ significantly from those of their respective counterparts who did not consume orange juice daily. A previous study showed that consumption of orange juice below $750 \mathrm{~mL} / \mathrm{d}$ did not affect serum homocysteine levels [18]. However, another author observed that serum homocysteine levels only decreased when daily folate intake reached $250 \mu \mathrm{g}$ [42]. More recently, a study found that daily intake of 250 to $500 \mu \mathrm{g}$ of folate reduced serum homocysteine levels by 11 to $20 \%$ [42]. Dosages below $250 \mu \mathrm{g} / \mathrm{d}$ do not seem to affect serum homocysteine levels significantly; nevertheless, orange juice still contributes to the total daily folate intake.

The present study found an inverse correlation between serum homocysteine levels and apo A-I, which is in agreement with a recent study of patients with coronary artery disease [42]. A positive correlation was also observed between serum homocysteine levels and serum triglycerides $(\mathrm{r}=0.17, \mathrm{p}<0.04)$. A study in animals found a direct relationship between high homocysteine levels and changes in lipid metabolism that increased the risk of coronary artery disease [43]. Most participants, who consumed orange juice regularly, showed a slight reduction in homocysteine levels, that is, $8.5 \%$ in normolipidemic individuals and $11 \%$ in hypercholesterolemic individuals, although not significantly. High homocysteine levels in humans and animals are associated with endothelial dysfunction, accumulation of fats in the liver, low HDL- cholesterol and a slight change in total cholesterol [42,44]. An experimental study using supra physiological dosages of homocysteine found that the underlying mechanism involves inhibition of apo A-I synthesis in the liver and consequent reduction of serum HDL- cholesterol and its functional and anti-inflammatory activities on the endothelium [44].

The dietary intake of saturated fat and cholesterol of the normolipidemic orange juice consumers or non-consumers was close to the dietary guidelines of American Heart Association [23]. On the other hand, hypercholesterolemic subjects, both consumers and non-consumers, had higher intake of dietary cholesterol (> $300 \mathrm{mg} / \mathrm{d}$ ), but the dietary saturated fat followed the recommended allowance $(<7 \%$ of total food energy intake). One of the strategies to reduce serum cholesterol according to the AHA is to consume foods containing stanol/sterol esters, such as orange juice fortified with stanol ester, or foods high in bioactive compounds which can improve the lipid profile [23].
The present study found that orange juice consumers had on average lower serum levels of total cholesterol and LDL-cholesterol in comparison with non-consumers. Presumably these effects are related to citrus flavonoid compounds found in orange juice $[5,43]$. In vivo studies have shown that naringenin and hesperitin inhibited ACAT and microsomal transfer protein (MTP) activities, which are responsible for the synthesis and esterification of the cholesterol in the liver [16], resulting in lower Apo $B$ secretion and consequently lower LDL-cholesterol levels [45]. Also a significant negative correlation was found between orange juice consumption and total cholesterol, LDL-cholesterol and LDL/HDL ratio in humans $[5,10,14,46]$. These study results elucidate the beneficial effect of orange juice on serum LDL-cholesterol levels in agreement with in vivo studies that demonstrate an effective cholesterol-lowering action of the bioactive components of orange juice, such as flavanones and vitamin C $[5,10,14,46]$.

Additionally a previous study showed a positive effect of orange juice on HDL-cholesterol levels with the consumption of $750 \mathrm{~mL}$ of orange juice per day [18], which was not verified in our study. Only $8 \%$ of our volunteers (data not shown) had a daily orange juice consumption that matched or exceeded the consumption of $750 \mathrm{~mL}$ per day, which may account for the difference.

The average of apo B and LDL-cholesterol of the orange juice consumers was lower in both normolipidemic and hyperlipidemic groups. Furthermore, an inverse correlation was found between regular orange juice consumption and apo $\mathrm{B}$, reinforcing the LDL-cholesterol lowering effect of orange juice. An in vitro study found that hesperidin and naringin reduced the availability of lipids for assembly of apo B-containing lipoproteins: VLDL- and LDL-cholesterol, which is attributed to reduced ACAT 1 and ACAT 2 activities, selective decrease in ACAT 2 expression and reduced microsomal triglyceride transfer protein activity [16].

Serum triglyceride levels were statistically different between consumers and non-consumers of orange juice, despite the presence of sugars in the juice; however they were higher in the hypercholesterolemic group than in the normolipidemic. Animals given orange or grapefruit flavanones daily experienced a reduction in serum triglyceride levels [47] but studies with human beings have suggested that the magnitude of their effect on triglyceride levels depends primarily on other factors, such as age, gender, fasting glucose, insulin and triglyceride levels, insulin resistance and total fructose intake [36].

Although a smoking habit has been associated with a significant increase of stroke, high blood pressure, and damage to the arterial wall contributing to atherosclerosis, all of them considered as risk factors for cardiovascular disease [23], this behavior was not investigated in this study. The main focus of this investigation were the 
markers of lipid metabolism due to the benefit of the orange juice on total cholesterol and LDL-cholesterol in women and hyperlipidemic men, as previously detected from these authors $[13,14]$.

The first strength of this study was the volunteers have been already exposed to daily orange juice consumption and that they freely chose to consume or not. The second strength of this study was the exposure of individuals to the same main meals every day (breakfast and lunch). This environment was more homogeneous than individuals who had their meals at home or in different places. Nevertheless, be exposed to the same food environment, does not mean they ate the same foods. Therefore, the assessment of food consumption was conducted through the individual 24-hour recall. The limitation, however, was that the dietary information was obtained through a selfreported questionnaire, which may be subject to under or over reporting and interviewer bias, and because of the cross-sectional design, which is limited in verifying any relationship between cause and effect.

\section{Conclusions}

This study suggested that long-term consumption of orange juice by normolipidemic and hypercholesterolemic subjects was not associated with weight or body fat, or plasma triglyceride and homocysteine. It was, however, associated with reduced total cholesterol, LDL-cholesterol, apo B and LDL/HDL ratio. Hence, it corroborated the hypothesis that long-term orange juice consumption was significantly associated with favorable effects on risk factors for cardiovascular disease, suggesting that future research should test whether orange juice can be useful as a secondary intervention in subjects with normal or moderately high serum cholesterol.

\section{Methods}

\section{Subjects and study design}

It was a descriptive and cross-sectional study with healthy volunteers who worked at Citrosuco (Fischer S/A Comercio Industria e Agricultura), an orange juice factory located in Matao, SP, Brazil. A total of 129 volunteers were selected to participate in this study, 103 men aged 18 to $66 \mathrm{y}$ and 26 women aged 18 to $65 \mathrm{y}$. None of the 129 participants had thyroid, kidney, or heart disease, diabetes, or required the use of pharmaceuticals, and those who consumed more than zero but less than one cup of orange juice per day ( $>0$ or $<240 \mathrm{~mL} / \mathrm{d}$ ) were excluded of the sample as well. The study was approved by the Ethics Committee of the School of Pharmaceutical Sciences, São Paulo State University, and an informed written consent was obtained from each participant.

General and anthropometric data were collected over a four-week period by the researchers of this study. During the first week of the experiment, blood samples were obtained from the median cubical vein and placed in EDTA-containing vials. Serum samples were centrifuged at $3,000 \times \mathrm{g}$ for $10 \mathrm{~min}$ at room temperature within $1 \mathrm{~h}$ of collection and stored at $-80^{\circ} \mathrm{C}$ until the assays of total cholesterol, HDL-cholesterol, triglycerides, apoA1, apo B, homocysteine, were performed at the Clinical Analyses Laboratory, School of Pharmaceutical Sciences, UNESP, Araraquara, SP. Reagents and instruments used for these analyses are described on the Biochemical Tests section.

Daily consumption of foods and beverages was determined with two 24-h recalls, described in "Dietary assessment" section, conducted by the researchers during four weeks of the experimental period. Nutritional requirements were estimated according to the National Research Council [28]. The frequency of the consumption of orange juice was obtained with the first dietary recall and all consumers stated that their primary source was the orange juice from the company cafeteria. The specific question addressed to the volunteers was: "How much and how often did you drink orange juice during the last 12 months?" Those who reported drinking orange juice every day, one to more cups per day, in the last twelve months were selected as habitual consumers of orange juice $(n=50)$, with an average intake of $480 \pm 158 \mathrm{~mL} / \mathrm{d}$. Those who did not drink orange juice during the last twelve months (0 cup/d), as non-consumers $(n=79)$. Those who consumed some orange juice, but less than one cup per day $(240 \mathrm{~mL} / \mathrm{d})$ were excluded of the sample. All collected data were observational and descriptive of the usual and spontaneous orange juice intake by the volunteers.

Dietary, physical activity and anthropometric variables of men and women were analyzed separately because of the distinct gender characteristics for these variables. Because dyslipidemias are under strong genetic influence, the volunteers were divided into those with normal cholesterol levels $(n=90$, total cholesterol $<6.2 \mathrm{mmol} / \mathrm{L})$ and those with moderately high cholesterol levels $(n=39$, total cholesterol $\geq 6.2 \mathrm{mmol} / \mathrm{L}$ ) in order to evaluate the individual influence of orange juice on the blood lipid profile.

\section{Orange juice composition}

Commercially processed orange juice $\left(12^{\circ}\right.$ Brix, reconstituted from concentrate) was provided daily in the company restaurant as their primary source of orange juice as reported by the volunteers. The average daily serving of orange juice $(480 \mathrm{~mL})$ contained approximately $161 \mathrm{mg}$ of vitamin $\mathrm{C}, 90 \mu \mathrm{g}$ of folate, $851 \mathrm{mg}$ of potassium, $40 \mathrm{~g}$ of total sugar (19 $\mathrm{g}$ of sucrose, $10 \mathrm{~g}$ of glucose, $11 \mathrm{~g}$ of fructose) and $970 \mathrm{~kJ}(234 \mathrm{kcal})$ [48]. The flavonoid content in $480 \mathrm{~mL}$ of orange juice was estimated at $26.4 \mathrm{mg}$ of hesperitin and $7.4 \mathrm{mg}$ of naringenin [48]. 
Daily orange juice consumption estimates were determined indirectly by self-reporting from all the volunteers.

\section{Dietary assessment}

Daily consumption of food and beverage was determined by a 24-hour food recall and analyzed with a computerbased data evaluation system (NUTRI software, version 2.5 CIS, Federal University of Sao Paulo School of Medicine, Brazil). Food intakes were described in terms of portion sizes, and sugar and lipid consumption was estimated from the food preparation. Food energy intake was estimated from the consumption of macronutrients in the 24-hour food recall (Table 1), where $1 \mathrm{~g}$ of protein or carbohydrate equals $16.7 \mathrm{~kJ}$ and $1 \mathrm{~g}$ of lipid equals $37.7 \mathrm{~kJ}$. The nutritional requirements of all individuals were estimated according to the National Research Council [28].

\section{Anthropometric and physical activity assessment}

Body weight $(\mathrm{kg})$ and height $(\mathrm{m})$ were measured for all volunteers and body mass index (BMI) was determined (weight/height ${ }^{2}$ ) [49]. Waist circumference (narrowest diameter between xiphoid process and iliac crest) was measured in triplicate at one time for each subject, and the average was taken as the final determination [50]. Bipolar body electrical bioimpedance was assessed early in the morning to determine body fat, before the participants had broken the overnight fast (Biodynamics Model 310e, Seattle, WA, USA). An electric current of $0.8 \mathrm{~mA}$ and $50 \mathrm{kHz}$ was produced by a calibrated signal generator and applied to the skin using adhesive electrodes placed on right-side limbs [50].

Physical activity was investigated with the first 24-h recall, by four specific questions: practice or non-practice of physical activity, type of exercise, duration (h/d) and frequency (times/wk). All these parameters were used to determinate the physical activity coefficient (PA), which represents four categories of life style, as sedentary, low active, active and very active, according to gender and BMI [28].

\section{Biochemical tests}

Total serum cholesterol (CHOD-PAP; Roche), triacylglycerol (Triglyceride Rapid; Roche), and HDL-cholesterol (HDL Reagent Roche) were determined enzymatically by an automated biochemical analyzer (Roche Cobas e601, Switzerland). LDL-cholesterol was estimated by Friedewald's equation (1972) [51]. Apolipoprotein A (apo A-I) and apolipoprotein B (apo B) were determined by immunoturbidimetric assay using commercial kits (Roche Diagnostics, Germany) in a Cobas MIRA analyzer (Roche, Switzerland). Homocysteine (IMx Metabolic - Homocysteine, Abbott Laboratory) was determined by the Axsym system immunological method by fluorescence polarization (AXSYM, Abbott, Wiesbaden, Germany).

\section{Statistical analyses}

Sample size was calculated to detect means differences with $90 \%$ power and 5\% significance. Data were expressed as mean \pm standard deviation. The distribution of variables was analyzed with Kolmogorov-Smirnov test. Variables with normal distribution were analyzed with a Student's $t$-test. Non-parametric variables were analyzed with the W-Wilcoxon test. Associations between orange juice consumption and variables were analyzed using a Spearman's correlation. p-value of 0.05 was used to define significance. The data were analyzed using Sigma Stat for Windows ${ }^{\oplus}$ (version 3.11, 2004 Systat Software Inc, USA).

\section{Abbreviations \\ ACAT acyl CoA: Cholesterol acyltransferase; apo A-I: Apolipoprotein A; apo B: Apolipoprotein B; BMI: Body mass index; HDL: High-density lipoprotein; HMG-CoA 3: Hydroxy-3-methyl-glutaryl coenzyme A; LDL: Low-density lipoprotein; MTP: Microsomal transfer protein; VLDL: Very low-density lipoprotein.}

\section{Competing interests}

The authors state that there is no conflict of interest and that they are responsible for the content and writing of the paper.

\section{Authors' contributions}

NPA has collected and arranged the data of the trial and TBC drafted the manuscript. TBC was the principal investigator of the project and has made the conception and design of the study, and also guided in the analysis and statistical design of research trial. NPA helped to carry out the statistical analysis. Both authors have given final approval of the version to be published.

\section{Acknowledgment}

The authors thank Citrosuco, Orange Brazil Association, and Support Program for Scientific Development of the Faculty of Pharmaceutical Sciences, Sao Paulo State University, Brazil, for sponsoring the study.

\section{Received: 7 May 2013 Accepted: 1 August 2013}

Published: 6 August 2013

\section{References}

1. Obrenovich ME, Li Y, Parvathaneni K, Yendluri BB, Palacios HH, Leszek J, Aliev G: Antioxidants in health, disease and aging. CNS Neurol Disord Drug Targets 2011, 10(2):192-207.

2. Basu A, Rhone M, Lyons TJ: Berries: emerging impact on cardiovascular health. Nutr Rev 2010, 68:168-177.

3. Calder PC, Albers R, Antoine JM, Blum S, Bourdet-Sicard R, Ferns GA, Folkerts G, Friedmann PS, Frost GS, Guarner F, Løvik M, Macfarlane S, Meyer PD, M'Rabet L, Serafini M, van Eden W, van Loo J, Vas Dias W, Vidry S, Winklhofer-Roob BM, Zhao J: Inflammatory disease processes and interactions with nutrition. Br J Nutr 2009, 101(Suppl 1):S1-S45.

4. Holt EM, Steffen LM, Moran A, Basu S, Steinberger J, Ross JA, Hong CP, AR: Fruit and vegetable consumption and its relation to markers of inflammation and oxidative stress in adolescents. J Am Diet Assoc 2009, 109:414-421.

5. Roza JM, Xian-Liu Z, Guthrie N: Effect of citrus flavonoids and tocotrienols on serum cholesterol levels in hypercholesterolemic subjects. Altern Ther Health Med 2007, 13:44-48.

6. Chun OK, Chung SJ, Song WO: Estimated dietary flavonoid intake and major food sources of U.S. adults. J Nutr 2007, 137:1244-1252.

7. Arabbi PR, Genovese MI, Lajolo FM: Flavonoids in vegetable foods commonly consumed in Brazil and estimated ingestion by the Brazilian population. J Agric Food Chem 2004, 52:1124-1131.

8. Rice-Evans C, Miller NG, Paganga G: Structure antioxidant activity relationships of flavonoids and phenolic acids. Free Rad Biol Med 1996, 20(7):833-956.

9. Miyake Y, Yamamoto K, Tsujihara N, Osawa T: Protective effects of lemon flavonoids on oxidative stress in diabetic rats. Lipids 1998, 33:689-695. 
10. Franke AA, Cooney RV, Henning SM, Custer LJ: Bioavailability and antioxidant effects of orange juice components in humans. J Agric Food Chem 2005, 53:5170-5178.

11. Crespo ME, Galvez J, Cruz T, Ocete MA, Zarzuelo A: Antiinflammatory activity of diosmin and hesperidin in rat colitis induced by TNBS. Planta Med 1999, 65:651-653.

12. Montforte MT, Trovato A, Kirjavainen S, Forestieri AM, Galati EM, Lo Curto RB: Biological effects of hesperidin a citrus flavonoid hypolipidemic activity on experimental hypercholesterolemia in rat. Farmaco 1995, 50:595-599.

13. Aptekmann NP, Cesar TB: Orange juice improved lipid profile and blood lactate of overweight middle-aged women subjected to aerobic training. Maturitas 2010, 67:343-347.

14. Cesar TB, Aptekmann NP, Araujo MP, Vinagre CC, Maranhão RC: Orange juice decreases low-density lipoprotein cholesterol in hypercholesterolemic subjects and improves lipid transfer to high-density lipoprotein in normal and hypercholesterolemic subjects. Nutr Res 2010, 30:689-694.

15. Rizza S, Muniyappa R, lantorno M, Kim JA, Chen H, Pullikotil P, Senese N, Tesauro M, Lauro D, Cardillo C, Quon MJ: Citrus polyphenol hesperidin Stimulates production of nitric oxide in endothelial cells while improving endothelial function and reducing inflammatory markers in patients with metabolic syndrome. J Clin Endocrinol Metab 2011, 96(5):E782-E792.

16. Wilcox $L$, Borradaile NM, de Dreu LE, Huff MW: Secretion of hepatocyte apo $B$ is inhibited by the flavonoids, naringenin and hesperetin, via reduced activity and expression of ACAT2 and MTP. J Lipid Res 2001, 42:725-734.

17. Borradaile NM, Carroll KK, Kurowska EM: Regulation of HepG2 cell apolipoprotein $\mathrm{B}$ metabolism by the citrus flavanones hesperetin and naringenin. Lipids 1999, 34:591-598.

18. Kurowska EM, Spence JD, Jordan J, Wetmore S, Freeman DJ, Piché LA, Serratore $\mathrm{P}$ : $\mathrm{HDL}$-cholesterol-raising effect of orange juice in subjects with hypercholesterolemia. Am J ClinNutr 2000, 72(5):1095-1100.

19. Knekt $P$, Kumpulainen J, Järvinen $R$, Rissanen $H$, Heliövaara $M$, Reunanen $A$, Hakulinen T, Aromaa A: Flavonoid intake and risk of chronic diseases. Am J Clin Nutr 2002, 76:560-568.

20. Riso P, Visioli F, Gardana C, Grande S, Grande S, Brusamolino A, Galvano F, Galvano G, Porrini M: Effects of blood orange juice intake on antioxidant bioavailability and on different markers related to oxidative stress. J Agric Food Chem 2005, 53:941-947.

21. Sánchez-Moreno C, Cano MP, Ancos B, Plaza L, Olmedilla B, Granado F, Martín A: High-pressurized orange juice consumption affects plasma vitamin $C$, antioxidative status and inflammatory markers in healthy humans. J Nutr 2003, 133:2204-2209.

22. Moat SJ, Lang D, McDowell IF, Clarke ZL, Madhavan AK, Lewis MJ, Goodfellow J: Folate, homocysteine, endothelial function and cardiovascular disease. J Nutr Biochem 2004, 15(2):64-79.

23. Fletcher B, Berra K, Ades P, Braun LT, Burke LE, Durstine JL, Fair JM, Fletcher GF, Goff D, Hayman LL, Hiatt WR, Miller NH, Krauss R, Kris-Etherton P, Stone N, Wilterdink J, Winston M: Council on Cardiovascular Nursing; Council on Arteriosclerosis, Thrombosis, and Vascular Biology; Council on Basic Cardiovascular Sciences; Council on Cardiovascular Disease in the Young; Council on Clinical Cardiology; Council on Epidemiology and Prevention; Council on Nutrition, Physical Activity, and Metabolism; Council on Stroke; Preventive Cardiovascular Nurses Association. Managing abnormal blood lipids: a collaborative approach. Circulation 2005, 112(20):3184-3209.

24. Eilat-Adar S, Goldbourt U: Nutritional recommendations for preventing coronary heart disease in women: evidence concerning whole foods and supplements. Nutr Metab Cardiovasc Dis 2010, 20(6):459-466.

25. Mulvihill EE, Huff MW: Antiatherogenic properties of flavonoids: implications for cardiovascular health. Can J Cardiol 2010(Supp|A):17A-21A.

26. Craig WJ: Nutrition concerns and health effects of vegetarian diets. Nutr Clan Pact 2010, 25(6):613-620.

27. Whitman SC, Kurowska EM, Manthey JA, Daugherty A: Nobiletin, a citrus flavonoid isolated from tangerines, selectively inhibits class a scavenger receptor-mediated metabolism of acetylated LDL by mouse macrophages. Atherosclerosis 2005, 178:25-32.

28. The National Academies Press (2005) Dietary Reference Intakes for Energy, Carbohydrate, Fiber, Fat, Fatty Acids, Cholesterol, Protein, and Amino Acids (Macronutrients). [http://www.nap.edu/openbook.php?isbn=0309085373]
29. Popkin BM, Armstrong LE, Bray GM, Caballero B, Frei B, Willett WC: A new proposed guidance system for beverage consumption in the United States. Am J Clin Nutr 2006, 83:529-542.

30. Sartorelli DS, Franco L, Gimeno SG, Ferreira SR, Cardoso MA: Japanese-Brazilian Diabetes Study Group. Dietary fructose, fruits, fruit juices and glucose tolerance status in Japanese-Brazilians. Nutr Metab Cardiovasc Dis 2009, 19(2):77-83.

31. Rivera JA, Muñoz-Hernández $O$, Rosas-Peralta $M$, Aguilar-Salinas CA, Popkin BM, Willett WC: Comité de Expertos para las Recomendaciones. [Beverage consumption for a healthy life: recommendations for the Mexican population]. Salud Publica Mex 2008, 50(2):173-195.

32. Ruxton CH, Gardner EJ, Walker D: Can pure fruit and vegetable juices protect against cancer and cardiovascular disease too? A review of the evidence. Int J Food Sci Nutr 2006, 57(3-4):249-272.

33. Schulz M, Hoffmann $K$, Weikert $C$, Nöthlings $U$, Schulze MB, Boeing $H$ : Identification of a dietary pattern characterized by high-fat food choices associated with increased risk of breast cancer: the European Prospective Investigation into Cancer and Nutrition (EPIC)-Potsdam Study. Br J Nutr 2008, 100(5):942-946.

34. O'Neil CE, Nicklas TA, Rampersaud GC, Fulgoni VL: 3rd One hundred percent orange juice consumption is associated with better diet quality, improved nutrient adequacy, and no increased risk for overweight/ obesity in children. Nutr Res 2011, 31(9):673-682.

35. Sharma AM: The obese patient with diabetes mellitus: from research targets to treatment options. Am J Med 2006, 119(Suppl 1):S17-S23.

36. Deopurkar R, Ghanim H, Friedman J, Abuaysheh S, Sia CL, Mohanty P, Viswanathan $P$, Chaudhuri A, Dandona P: Differential effects of cream, glucose, and orange juice on inflammation, endotoxin, and the expression of Toll-like receptor-4 and suppressor of cytokine signaling-3. Diabetes Care 2010, 33(5):991-997.

37. Morand C, Dubray C, Milenkovic D, Lioger D, Martin JF, Scalbert A, Mazur A: Hesperidin contributes to the vascular protective effects of orange juice: a randomized crossover study in healthy volunteers. Am J ClinNutr 2011 93(1):73-80.

38. Rampersaud GC: A comparison of nutrient density scores for $100 \%$ fruit juices. J Food Sci 2007, 72(4):S261-S266.

39. O'Neil CE, Nicklas TA, Rampersaud GC, Fulgoni VL 3rd: 100\% orange juice consumption is associated with better diet quality, improved nutrient adequacy, decreased risk for obesity, and improved biomarkers of health in adults: National Health and Nutrition Examination Survey, 2003-2006. Nutr J 2012, 11:107.

40. Hirsch S, Pia De la Maza M, Yañez P, Glasinovic A, Petermann M, Barrera G, Gattas V, Escobar E, Bunout D: Hyperhomocysteinemia and endothelial function in young subjects: effects of vitamin supplementation. Clin Cardiol 2002, 25(11):495-501.

41. Brouwer IA, van Dusseldorp M, West CE, Meyboom S, Thomas CM, Duran M, van het Hof KH, Eskes TK, Hautvast JG, Steegers-Theunissen RP: Dietary folate from vegetables and citrus fruit decreases plasma homocysteine concentrations in humans in a dietary controlled trial. J Nutr 1999, 129(6):1135-1139.

42. Liao D, Yang $X$, Wang $H$ : Hyperhomocysteinemia and high-density lipoprotein metabolism in cardiovascular disease. Clin Chem Lab Med 2007, 45(12):1652-1659.

43. Mikael LG, Genest J Jr, Rozen R: Elevated homocysteine reduces apolipoprotein A-I expression in hyperhomocysteinemic mice and in males with coronary artery disease. Circ Res 2006, 98(4):564-571.

44. Schwab U, Törrönen A, Toppinen L, Alfthan G, Saarinen M, Aro A, Uusitupa M: Betaine supplementation decreases plasma homocysteine concentrations but does not affect body weight, body composition, or resting energy expenditure in human subjects. Am J Clin Nutr 2002, 76(5):961-967.

45. Kurowska EM, Manthey JA: Hypolipidemic effects and absorption of citrus polymethoxylated flavones in hamsters with diet-induced hypercholesterolemia. J Agric Food Chem 2004, 52(10):2879-2886.

46. Bok SH, Lee SH, Park YB, Bae KH, Son KH, Jeong TS, Choi MS: Plasma and hepatic cholesterol and hepatic activities of 3-hydroxy-3-methyl-glutaryl-CoA reductase and acyl $\mathrm{CoA}$ : cholesterol transferase are lower in rats fed citrus peel extract or a mixture of citrus bioflavonoids. J Nutr 1999, 129(6):1182-1185.

47. Manthey JA, Cesar TB, Jackson E, Mertens-Talcott S: Pharmacokinetic study of nobiletin and tangeretin in rat serum by high-performance liquid chromatography-electrospray ionization-mass spectrometry. J Agric Food Chem 2011, 59(1):145-151. 
48. U.S. Department of Agriculture, Agricultural Research Service: USDA National Nutrient Database for Standard Reference, Release 25. Nutrient Data Laboratory; 2012. Home Page [http://www.cnpp.usda.gov/Publications/ Nutritionlnsights/Insight16.pdf]

49. Hiza HA, Pratt C, Mardis AL, Anand R: Body mass index and health. Center for Nutrition Policy and Promotion, U.S. Department of Agriculture. http://www. ars.usda.gov/main/site_main.htm?modecode=12-35-45-00.

50. National Center for Health Statistics: The NHANES anthropometry procedures manual; 2004. http://www.cdc.gov/nchs/data/nhanes/nhanes_09_10/ BodyMeasures_09.pdf.

51. Friedewald WT, Levy Rl, Frenrcckson DS: Estimation of the concentration of low-density lipoprotein cholesterol in plasma, without use of the preparative ultracentrifuge. Clin Chem 1972, 18:499-502.

doi:10.1186/1476-511X-12-119

Cite this article as: Aptekmann and Cesar: Long-term orange juice consumption is associated with low LDL-cholesterol and apolipoprotein $\mathrm{B}$ in normal and moderately hypercholesterolemic subjects. Lipids in Health and Disease 2013 12:119.

\section{Submit your next manuscript to BioMed Central and take full advantage of:}

- Convenient online submission

- Thorough peer review

- No space constraints or color figure charges

- Immediate publication on acceptance

- Inclusion in PubMed, CAS, Scopus and Google Scholar

- Research which is freely available for redistribution 